\title{
OPPORTUNITIES, CHALLENGES AND CITIZEN'S VIEWPOINT \\ OF ECOTOURISM IN AZERBAIJAN: \\ CASE STUDY OF SHAHDAG NATIONAL PARK
}

\author{
Ibrahim Asadov ${ }^{1}$ \\ Éva Erdélyi ${ }^{2}$ (ii)
}

DOI: https://doi.org/10.31410/tmt.2020.167

\begin{abstract}
Growing dissatisfaction with mass tourism, ecotourism had become a major tool for achieving conservation and sustainable development goals by many developing countries by the mid. 1980s. Today, it is a major source of income for many developing countries across the world with being less destructive in the usage of natural resources than alternative economic sectors such as agriculture and logging. This study is concentrated on investigating and researching ecotourism within the context of national parks, more precisely within Shahdag National Park (SNP) of Azerbaijan. This study aims to find the existing gaps, disadvantages and challenges in the ecotourism system of SNP, identify the opinion and level of education of people of Azerbaijan about ecotourism and sustainability in general. To identify these, data were collected, and both quantitative and qualitative methods were implemented. Primary research included a questionnaire survey and interview. As the main result, it can be concluded that Shahdag National Park of Azerbaijan has immense ecotourism potential but this potential is not utilized to its fullest capacity.
\end{abstract}

Keywords: Azerbaijan, Ecotourism, Protected area, Shahdag National Park.

\section{INTRODUCTION}

$\mathrm{T}$ he environmental revolution of the 1960s and ' 70 s triggered the emergence of environmental awareness and immediate actions. Mass tourism has negative ecological and social effects. Governments and organizations started to make their first steps in the process of transformation from traditional mass tourism into more sustainable ways of tourism. As a result, a new, sustainable type of tourism, ecotourism, came into the light. Practitioners of ecotourism are environmentally conscious people, who are eager to get more information about the local ecosystem and ecoculture. Ecotourists are mainly ecologically educated and responsible individuals, who are always ready to pay more than average tourists for their trips. The development of ecotourism is included in the national development plan of the Republic of Azerbaijan, either. The year 2011 was declared as a year of tourism by the government of Azerbaijan. Ecotourism has significant perspectives and opportunities in Azerbaijan. However, the potential of ecotourism in Azerbaijan is not utilized to its maximum capacity. Under the detailed and strategic ecotourism development strategy, Azerbaijan can develop its ecotourism system and achieve one of its national development goals.

National Parks are II category protected areas among 6 protected area categories accredited by the International Union for Conservation of Nature (IUCN). They are large natural or near natural areas designated to protect ecological processes of a large scale, together with biological species and area specific ecosystems, which also provide environmentally and culturally compatible opportunities for scientific, educational, visitor, spiritual, and recreational purposes.

\footnotetext{
$1 \quad$ Budapest Business School - University of Applied Sciences, H- 1054 Budapest, Alkotmány utca 9-11, Hungary

2 Budapest Business School - University of Applied Sciences, H- 1054 Budapest, Alkotmány utca 9-11, Hungary
} 
There are eight National Parks in Azerbaijan. The biggest and the most diverse NP - Shahdag National Park was opened on 8th December of 2006. It is located across the Greater Caucasus mountain range. The area of the park is 130,508 ha, (The Ministry of Ecology and Natural Resources of Azerbaijan, 2005-2020). The hypothesis of this research is that SNP has great ecotourism potential, however, this potential is not utilized to its maximum capacity.

The aims and objectives of this study include unleashing the ecotourism potential of Shahdag National Park once again; identifying challenges of the park depriving it of successful ecotourism development; identifying and showing the local population's viewpoint about ecotourism. Research questions of this project included: What are the existing challenges in the ecotourism system of SNP? What are the further development opportunities in the ecotourism of SNP? What are Azerbaijani people viewpoints of ecotourism? The research hypothesis is that higher investment in SNP will lead to more visitors, hence more profit. It is possible to achieve it because the national park has immense ecotourism potential but this potential is not utilized to its fullest capacity.

\section{LITERATURE REVIEW}

'Mother nature' has always astonished humans with her mesmerizing beauty, mysteries and rich ecosystem. Even before Thomas Cook established the first ever travel agency in the world in 1841 (Gartner, 1996) or young, rich Europeans undertook once in a life time "Grand Tour", people have always travelled and wondered about nature. The purposes and needs behind it were different such as self-exploration, fulfillment, social interaction, authenticity, self-actualization, education, relaxation or just plain curiosity. Known mainly as Ecotourism, this phenomenon of sustainable tourism has been widely discussed among many researchers, practitioners and proponents in literature. It has been referred interchangeably to terms such as nature tourism, ecological tourism, sustainable tourism, alternative tourism, cultural tourism and heritage tourism. S. Wheat in 1994 defined ecotourism as a niche market for a special category of tourists who are interested in observing nature and have environmental awareness (Wheat, 1994). According to Steel (1993) it is an economic process where rare and attractive ecosystems are marketed in an international level to attract tourists (Steel, 1993). It is travelling to the unique, undisturbed and uncontaminated destinations all across the planet earth for admiring or studying the mesmerizing nature, enjoying its wild animals and plants as well as existing past or present cultural and traditional manifestations found in those areas (Ceballos-Lascurain, 1987). "Ecotourism is a travel to fragile, pristine and usually protected areas that strives to be low impact and usually small scale. It helps educate the traveller, provides funds for conservation, directly benefits the economic development and political empowerment of local communities and fosters respect for different cultures and human rights" (Honey, 1999) (Honey(ed), 2002).

The United Nations World Tourism Organization (UNWTO) defined ecotourism, its' definition, principles and characteristics. According to them, ecotourism is all forms of nature-based tourism activities where the visitors' main aim is to observe, appreciate natural attractions and traditional cultures prevailing in them (WTO, 2001). According to The International Ecotourism Society (TIES), Ecotourism is "responsible travel to natural areas that conserves the environment and improves the well-being of local people" (TIES, 2015). Principles and characteristics identified by UNWTO dictate that the ecotourism experience should contain the following principles: It should include educational or interpretational features; the tours are organized generally but not exclusively by specialized tour operators for small groups and service providers in the destinations, that are locally owned small businesses; ecotourism minimizes the negative impacts 
on the natural and socio-cultural environment and supports the maintenance of natural areas or attractions by generating economic benefits for host community, authorities and organizations managing and preserving natural areas, providing extra income and employment opportunities for the local community and increasing awareness among locals and visitors about the conservation of the natural and cultural resources or assets (WTO, 2001).

\subsection{Protected Areas and National Parks}

According to the definition proposed by The International Union for Conservation of Nature (IUCN) in 2008, a protected area (PA) is a specifically defined natural area, acknowledged, devoted and maintained by means of legal or other efficient means to ensure long-term nature conservation with related ecological services and cultural values. Protected areas are a cornerstone of the conservation of natural resources, while still benefiting the living standards of people, especially at the community scale. Protected areas are at the forefront of initiatives to preserve nature and the resources it offers us with - nutrition, safe water supplies, medications, and defense from natural disaster outcomes. The global community widely acknowledges their involvement in reducing and addressing the climate change problems as well; it is considered that PAs reserve more than 15 percent of terrestrial carbon of the world within their worldwide network (IUCN, 2020). IUCN groups protected areas into six categories; one of them is National Park.

National Parks are large natural or near natural areas designated to protect ecological processes of a large scale, together with biological species and area specific ecosystems, which also provide environmentally and culturally compatible opportunities for scientific, educational, visitor, spiritual, and recreational purposes. The primary objective of NPs is the protection of natural biodiversity which includes its underlying ecological structure, supporting environmental processes, promoting education and recreation. Areas of NPs should be more strictly protected where ecological processes and the distribution of indigenous species remain reasonably untouched. Local landscape may have differing degrees of consumptive or non-consumptive applications but should ideally operate as defences to the protected region (IUCN, 2020).

\section{RESEARCH METHODOLOGY}

In this study, quantitative and qualitative methods of data collection were both applied. The survey with 19 questions covering all the aspects of the research questions and issues were delivered through online distribution channels to the Azerbaijani respondents of various age groups, occupations, background, nationality, etc. The number of the respondents in the research survey outreached 125 people, travellers of the country. The respondents were able to answer the questions with multiple-choice, rating scales, or add their comments. Analysing the causal relationship between variables and interpreting them helped to answer the research questions, identifying the viewpoint of Azerbaijani people about ecotourism. Quantitative methods are not sufficient to accurately simulate real-life situations and behaviours. Therefore, the implementation of qualitative methods, such as interviews were of as much as importance. The answers of some research questions came into the light after the interviews with the representative of the SNP and ecotourism specialists.

The methodology of the secondary research aims to find the existing gaps and disadvantages or challenges in the ecotourism system of SNP. Identifying opinions and level of education of the people of Azerbaijan about ecotourism and sustainability in general combined with the 
analysed literature will showcase future immense development opportunities in the field of ecotourism in SNP and help to answer main investigated issues of the research, and prove the hypotheses. Nevertheless, it is as much as important to coordinate the interests of local, regional, and national levels (Boo, 1990). However, we should not neglect the role of the private sector in the ecotourism development process. In this regard, Holder (1992: 159) emphasizes the dependence of the private sector on the government. Governments regulate the business environment of the countries, and they should create a favourable environment or conditions for the private businesses to thrive within certain limits in the ecotourism destinations. The government is responsible for the whole country as an ecotourism product in the broadest sense (Holder, 1992).

\section{RESEARCH RESULTS AND FINDINGS}

First, the ecotourism potential of Azerbaijan is summarised, protected areas of the country, focusing on Shahdag National Park.

"We have to admit regretfully that despite having such a colourful natural environment and resources, fertile lands, extremely precious climate and waters we have not valued them as they really are worth. We have never used them with conscious, strategical thinking and somehow impoverished our beautiful nature" (Müseyibov, 1998)

The Republic of Azerbaijan is a country with an ancient history located in the south-east of Caucasus region and north-west of Iranian plateau, where European and Asian continents meet. According to the calculations of R.X.Piriyev Azerbaijan has physical surface area of 88,278 square kilometres and with more than 10 million population Azerbaijan is the biggest country in the Caucasus region. The geographical location of Azerbaijan Republic is beneficial in terms of the natural and geopolitical environment. This was the main reason behind the interest of the big powers of ancient times in ruling these lands. The main natural-geographical benefits of Azerbaijan include its location in sub-tropical climatic zone (in the transition zone to temperate climatic zone), abundant natural resources of its lands, highly fertile soils of endless hills, wide sub-mountain and mountain systems with an extremely rich natural environment and resources and finally the biggest and the richest lake in the world - Caspian "sea" (Müseyibov, 1998).

Table 1. General information about National Parks in Azerbaijan

\begin{tabular}{|l|l|l|l|l|}
\hline № & Name & $\begin{array}{l}\text { Date of } \\
\text { establishment }\end{array}$ & Area (ha) & Location \\
\hline $\mathbf{1}$ & Absheron National Park & 08.02 .2005 & 783 & Khazar city \\
\hline $\mathbf{2}$ & Shirvan National Park & 05.07 .2003 & 54,373 & Salyan, Neftchala cities \\
\hline $\mathbf{3}$ & Aghgol National Park & 05.07 .2003 & 17,924 & Aghjabadi, Beylagan cities \\
\hline $\mathbf{4}$ & Hirkan National Park & 09.02 .2004 & 21,435 & Lankaran, Astara cities \\
\hline $\mathbf{5}$ & Altiaghac National Park & 31.11 .2004 & 11,035 & Khizi, Siyazan cities \\
\hline $\mathbf{6}$ & Shahdag National Park & 08.12 .2006 & 130,508 & Guba, Gusar, Oghuz cities \\
\hline $\mathbf{7}$ & Goygol National Park & 01.04 .2008 & 12,755 & Dashkasan, Goygol cities \\
\hline $\mathbf{8}$ & Ordubad National Park & 16.06 .2003 & 12,131 & Ordubad city \\
\hline
\end{tabular}

Source: table derived from (T.O.Ibrahimov, 2011), page 11.

There are currently 11 State Reserves, 8 National Parks and 24 State Game Reserves in Azerbaijan with an area of 3,6 \% of total area of the republic. These protected areas were created during the year 30 s of the last century with an aim to protect the mesmerizing nature of Azerbaijan and are 
still loyal to their initial vision and aim. The main goal for establishing the protecting areas was to develop ecotourism, to promote ecological awareness, increase the level of education, chant the richness of the nature of the region and boost the economic progress while maintaining the ecological balance and preserving the environment and natural attractions (Ә.T.Đsgərov, 2011). Table 1 provides general information about the National Parks in Azerbaijan (T.O.Ibrahimov, 2011).

Shahdag National Park was founded on $8^{\text {th }}$ December of 2006 in Azerbaijan. It is located across the Greater Caucasus mountain range. Which includes major regions such as Guba, Gusar, Ismayilli, Gabala, Oghuz and Shamakhi. The area of the park is 130,508 ha (The Ministry of Ecology and Natural Resources of Azerbaijan, 2005-2020). The aim of establishing SNP was protection, increasing and enrichment of numerous area specific endemic species (including trans-border migrating animal species), re-establishment, conservation and effective management of endemic rare species of flora and fauna which are already included into the "Red book", as well as mountain forests and high mountainous pastures ecosystem of global importance, conservation of the highly rich fertile layer of the soil, regulation of the stability of the NP, establishment of the favourable environment for scientific researches, monitoring of the local environment, ecologically educating the local population, development of ecotourism in the areas with high natural and touristic potential (Ә.T.Đsgərov, 2011) (Ministry of Ecology and Natural Resources, 2020). The locational altitude of the Shahdag National Park resulted forming a big variety within its climate, the richness of flora and fauna, and massive amount of highly fertile layer of soil. The forests of these areas are famous for their different, beautiful and majestic sceneries (Ә.T.Đsgərov, 2011)

Shahdag National Park is under the full management and control of the Ministry of Ecology and Natural Resources of Azerbaijan Republic (MENR). It also determines its rules, regulations, protection, prices, etc. (Ministry of Ecology and Natural Resources, 2020). MENR of Azerbaijan determined the rules that must be followed by visitors inside the national parks. According to them: Ecotourism activities can only be realized on the designated trails set by NP management; visitors cannot go off the official trails set by the NP authority and must follow the instructions of the guides, special maps and signs for safety purposes; throwing cigarette buds or burnt matches on the ground is prohibited; throwing any kind of trash, littering the territory, writing the surfaces of stones or trees and making any activity that will cause a high noise are highly prohibited; bonfires can be made only in designated fire places and it must be completely turned off upon leaving; it is highly advised to have an insurance for any sudden, unexpected event that can occur during the ecotourism experience; visitors can use the leisure, catering, accommodation and shopping services inside the NPs; visitors can collect information from the information centres of NPs; hunting and fishing inside the NPs are allowed only at the designated spots with an official permission of NP authority; Video and photo shootings are allowed inside NP; using observing devices, mobile phones and voice recording devices are allowed inside NPs; it is prohibited to use any flammable maters near the transportation vehicles or transportation stops of NPs (Ministry of Ecology and Natural Resources, 2020)

\subsection{Ecotourism attractions and activities in Shahdag National Park}

Development of the tourism sector is the priority and one of the development goals of the Republic of Azerbaijan, as mentioned earlier. Therefore, diversifying and creating various tourism products is also the priority for the central government. At the moment, tourism products of Azerbaijan include but are not limited to City breaks, sun-sea-sand tourism, eco/natural tourism, cultural tourism, health/wellness tourism, winter/ski tourism, gastronomy and wines 
tourism, MICE tourism (Meetings, Incentives, Conferences and Exhibitions), etc., (JICA, 2017). Being one of the most diverse in all means of this world and the biggest national park in Azerbaijan, Shahdag National Park offers to immerse opportunities for ecotourism and nature tourism. The uniqueness of SNP is that it offers these diverse opportunities for all seasons from cold winter and hot summer months. Skiing, snowboarding, snow-tubing, zip lining, snowmobile riding, hot thermal waters, resort complexes in cold seasons are perfect examples of some winter activities. Typical summer activities include hiking, mountain climbing, camping, wellness opportunities, and horseback riding, zip lining, cycling, visits to authentic villages, cultural activities, scientific research tours, other mountain adventures and so on. Skiing enthusiasts who are eager to try different slopes with beautiful scenery rather than traditional slopes can use the services of the 2 ski resorts located on Shahdag Mountains - Shahdag and Tufandagh Mountain Resort Complexes. These luxury resorts offer ski lovers world-class amenities, 14 high standard slopes, professional and friendly instructors and staff. World-class snow guns, ski lifts and cable cars are provided across the heights, throughout the ski area (Azerbaijan Travel, 2020), (Ski Azerbaijan, 2020). Both the territory of SNP and surrounding areas of the park include small and authentic Caucasus villages with their small population of ethnic minorities. These settlements include Laza, Lahij and Khinalig villages. These villages are popular and mostly visited by national visitors and some international tourists. Some tour companies organize one day tours to these villages. Visitors can self-organize multiple day tours to these villages if they manage to find accommodation in the villages, as ethnic population of these villages sometimes rent their houses to the visitors. While walking the narrow and authentic streets of these villages and enjoying the mesmerizing beauty of Caucasian mountains, tourists can also purchase locally produced spices, food, clothing, souvenirs and so on (AZERTAG, 2020).

Laza village is located in the Gusar region on the altitudes of 4,242 meters above sea level, making it one of the highest human settlements in Azerbaijan (Municipality Information System, 2020). It has more than 10 astonishingly beautiful waterfalls in the entire country. The village has approximately 170 inhabitants, living in 28 houses. The village is the favourite destination for tourists in all seasons. The village preserves its culture and traditions and is famous for its carpet making culture. In the year 2013, the municipality built the entrance post of Shahdag National Park inside the village (Yusifli, 2015). Khinalig village is located near the SNP, in the centre of Guba region, on the altitude of 2350 meters above sea level. The village also has a long history dating back to the times before our century of Caucasian Albania (Geography Association of Azerbaijan, 2013). The weather fluctuates between $(-20)$ and $(+18)$ degrees Celsius from winter to summer seasons. The population of the village is about 2000 people, which is related to Shahdag ethnic group. As a national minority, they have their own language, the unique character of architecture, culture and traditions. In 2008, Khinalig was included inside the World Monuments Funds' (WMF) list of 100 most endangered sites. Native people say legends that links this land with Prophet Noah. According to them Noah's Ark has thrown the anchor and settled in these areas because of its flat highland. The village is very famous among the national visitors (Mehmandarova, 1998), (Connor, 2001).

The village of Lahij is another prominent authentic village on the southern slopes of the Greater Caucasian Mountains. It is located inside the Ismailli region with a population of approximately 860 people. Minority people of Lahij speak Tat language (Miller, 1929). The village is very authentic and famous for their special handicrafts, particularly made from copper. Carpet and rug crafts of the village is also very famous in Azerbaijan. The village was an important centre of craftsmanship in Azerbaijan during the medieval times (G.A. Guliyev, 1968). Some local people of the village sell these crafts to the visitors and earn a living. The houses of Lahij village was 
built with authentic and sophisticated technics due to frequent earthquakes. The sewage system in the entire village dates back 1000-1500 years ago. (Alizadeh, 1986), (Bretanitskiy L.S., 1964). Although the village has high priority of cultural and historical importance the tourism, particularly ecotourism infrastructure of the village is underdeveloped, especially during winter months (Yahya, 2006). Shahdag National Park has six main eco-touristic trails (Ministry of Ecology and Natural Resources, 2020):

1. Laza waterfalls or frozen waterfalls,

2. Laza - mountain waterfalls,

3. Laza - Sudur,

4. Qeleyxudat - "Haydar" peak,

5. Khinalig village - Tufan mount or Chingiz Mustafayev,

6. Bazarduzu height.

\subsection{Ecotourism development plan}

For building an effective ecotourism system in one particular area, there should be a detailed ecotourism development plan. Ecotourism development plan are built based on three pillars of sustainability or sustainable tourism development (Nelson, 2016) (A. Barnett, 2015):

The socio-cultural pillar is important for gaining the support from the local people for implementing the ecotourism project as well as this aspect identifies major social and ecological problems. The socio-cultural aspect needs to be handled and considered before any other aspects because nothing can be implemented without the support of the local people. Foreign expertise cannot be directly implemented into one society without a deep analysis of the local culture, traditions, mind-set of people, and society. Understanding the ownership and occupancy of natural resources is also important to avoid conflicts. There is a need to establish new social and cultural norms in order to fully adapt to tourism.

The environmental pillar, being the second and important aspect of ecotourism implementation, can only be addressed after the local people are supporting the plan. At this pillar, it is important to manage the resources and implement mandatory research about their biology and ecology. The importance of this pillar derives from its main goal to sustain, preserve, and protect the environment. Another important factor in the process of development of ecotourism is to give local people benefits from it.

The economic aspect or pillar is the final step in the process of ecotourism development. The ideal implementation of this aspect is when the previous two pillars are going smoothly. Considering all the pillars, as mentioned earlier, we have to include that ecotourism development in certain areas of the earth must also offer economic benefits to that community and locals in particular. Local people should actively participate in this process and be employed by the employers directly, such as guides, hosts, mechanics, etc. If they lack certain knowledge about the roles or positions, they should be allowed to learn and develop themselves. Economic development often comes with costs despite its opportunities. In order to avoid these costs, there is a need to negotiate access rights, follow cultural protocols, and ensure protection against environmental damage.

The above-mentioned three pillars of sustainability are very important in the process of ecotourism development and allow us to build an effective ecotourism plan. However, in the real 
process of ecotourism development, many challenges can occur, and something can go wrong. The ecotourism development plan can be modified and changed along the realization process. It is a must for ecotourism models to have short-term coping mechanisms and long-term capacity building. After meeting all of these requirements, ecotourism can build a sustainable model for a particular destination benefitting society, economy, and environment.

\subsection{Interview results}

The interview has been conducted with the director of the Ismayilli region part of Shahdag National Park - Mr. Rafael Musayev. The interview was conducted online, through email, as the internet in Azerbaijan was limited because of the war situation. However, the interview was very productive and was vital in answering the research questions of this project. Mr. Rafael Musayev answered in a total of 6 important questions. These questions covered all the aspects and objectives of this research project. They were also vital in proving the hypothesis of the project. Director Musayev was very knowledgeable and very informative by describing his opinions and questions in a wide range. According to the interview Ismayilli region, part of SNP is 44 thousand ha. of the area. The area is covered with dense forests and has a rich ecosystem. Although Mr. Musayev is the director of this part, in particular, he answered the interview questions regarding whole SNP. According to him, 73,000 ha of land area of SNP is Strict Nature Reserve, which means that all kinds of human and other activities are prohibited in these areas except scientific researches. 4,500 ha of the area is reserved for agricultural purposes only. Nevertheless, the areas dedicated to ecotourism inside SNP consist of 51,000 hectares.

When it comes to the challenges of the ecotourism system of SNP, Mr. Musayev continued as follows. The first problem SNP faces from time to time is legal land issues with bordering private properties. When SNP was created, the territory of the park included some of the territories of 6 consecutive regions. Therefore, SNP borders with various lands with property rights along its borders. Doesn't matter what is the function of the particular land of SNP, but from time to time they face legal issues with other private lands. These problems arise when large and small horned animals of nearby animal farms migrate for grazing during the summer and winter months. Hence, it's creating the problem over the legal issues of the lands and property. Another challenge is related to trespassing or illegal anthropogenic impact. As we know, inside the big territory of SNP, there are some small villages of indigenous Caucasus people. Some of these villages are located on high altitudes over the mountains. They are not provided with natural gas, heating and with other infrastructure systems. Therefore, those people interfere and illegally consume some of the park's resources illegally from time to time. Nevertheless, Mr. Musayev also emphasized that the terms such as ecotourism and national or nature parks are relatively new and modern phenomena in Azerbaijan which are still underdeveloped.

The idea of ecotourism needs to be fully formalized by an Azerbaijani citizen and there is a lack of ecotourism or environmental education among many visitors. There is also a lack of experienced personnel, professionals in these fields. The current workers in these areas are less experienced as well comparing to the countries with foreign best ecotourism expertise. Promotion and marketing, especially online promotion of SNP and ecotourism are not at the desired level, which creates another big challenge. Lack of investment and support of different kinds from foreign organizations is also not desirable. General infrastructure is not at a good level inside SNP, and it has to be maintained properly. This includes, first of all, road systems, electricity, accommodation, lodging and so on. Lack of competition among very few accommodations and 
lodging service providers creates an unfair and expensive pricing strategy. He explained some of the above-mentioned challenges as the main reasons preventing SNP from fast development and being at the same level as some of the national parks with highly developed ecotourism systems around the world.

Mr. Musayev also emphasized the great ecotourism potential of SNP. This great potential is closely bounded to the size, immense natural, geographical, climatic variety. He mentioned some of the possible ideas or ecotourism activities that could be developed in SNP. The high-altitude Mountain Rivers of SNP create the perfect opportunity for developing extreme water sports, especially rafting. The high mountainous topography of the park is a great spot for more extreme hiking tours. The mesmerizing natural attractions, wildlife and green life of the park is great destination for organizing thematic tours for photography lovers. Seasonal natural phenomena such as fall of autumn leaves, migration of birds, mating season and spring migration of animals to natural salt rocks create once in a while natural events that could be observed and which can be of high interest for the visitors. Hunting tourism and bird watching can also be developed accordingly. Mr. Musayev mentioned that SNP is currently using just 10 percent of its ecotourism potential. The rest 90 percent of this potential is not implemented, and this is a very big room for development and opportunity in the future. Those undiscovered areas are less known among visitors. According to him, Azerbaijan has to develop rural tourism first for developing effective ecotourism in its national parks, developing the main ecotourism brand of the park and sub-brands of its different regions. Ecotourism products and other types of tourism have to be developed inside the park. The main visitors of the park are local, Azerbaijani visitors. One of the reasons is less international promotion and marketing. Another reason is the lack of accommodation and lodging choices inside the park and the unfair pricing strategy of these service providers. For the majority of ecotourists and backpackers, these services are not affordable, which is the result of the lack of competition among service providers as there are very few of them in the territory.

SNP is financially and technically supported and fully managed by the central government of Azerbaijan. There is a lack of funding and support for ecotourism development from foreign ecological, nature protection organizations, international development funds, etc. Generally, there very few national parks in Azerbaijan that are being funded by international organizations. Mr. Musayev has mentioned the benefits as well, and efficiency of self-governance and self-financing of national parks all around the world. It is tested with famous management method. He emphasized that by developing ecotourism inside SNP, we can also benefit from this world famous and effective method in the future.

\subsection{Survey results}

The data collecting phase of the research also included a survey which was used for data collection. The vast majority of the participants are from Azerbaijan. $61,9 \%$ of the participants belong to 25-34 years old age group. The second largest group belongs to 18-24 years old participants with $25,4 \%$. Age groups of 35 and above and less than 18 have $10,3 \%$ and 2,4 \% respectively. So, the majority of the participants were young people. The gender proportion of the participants were almost identical being 50,8 \% for females and 49,2 \% for males. Almost half of the respondents were male and female. However, their answers don't depend on gender according to data correlation analysis. 0,272 say they are ecotourists, 0,184 say they are not and the others are not sure. 110 participants $(89,4 \%)$ don't live in the territory of SNP or surrounding areas which means only $10,6 \%$ of the participants live either inside or surrounding areas of SNP. 


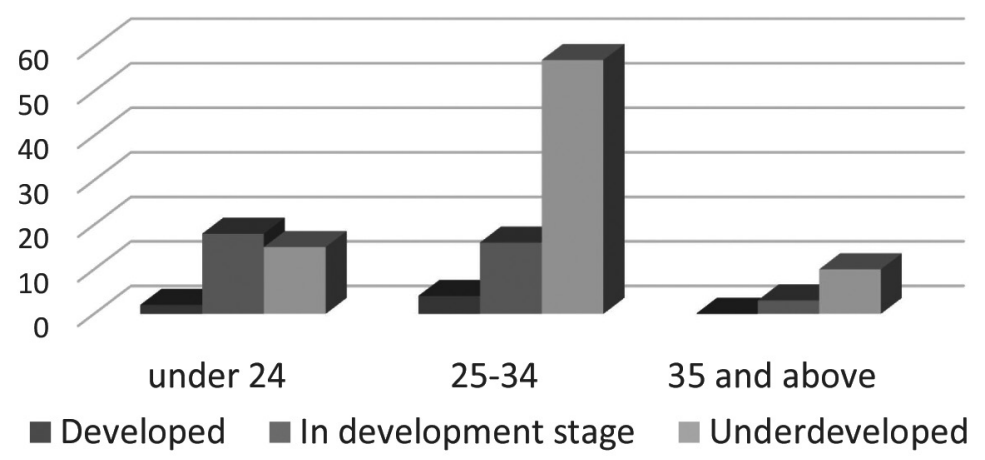

Figure 1. Opinion about Azerbaijan ecotourism depends on age group, youngest are optimistic

Source: based on own data processing and calculations

One of the main aims of this survey was to identify the ecotourism education level of participants, especially Azerbaijani population and showcase their viewpoint about ecotourism. The survey indicated that $60,3 \%$ (76 people) of participants were familiar with ecotourism and its principles. Whereas, 39,7\% (50 people) were not familiar with it. The result is not satisfying and shows a big percentage of people not having enough knowledge and appropriate ecotourism education. Amongst the total 126 participants, only 18,3\% (23 people) considered themselves as a true ecotourists. $27,8 \%$ (35 people) indicated that they are not ecotourists and as expected majority of the participants - $54 \%$ (68 people) claimed to be mixed practitioners (both ecotourism and regular tourists). Most of the respondents who said they are familiar with ecotourism and its' practices said they are ecotourists. According to the data, ecotourists also do not depend on the age group. The majority of the participants $(65,9 \%-83$ people) said that ecotourism in Azerbaijan is underdeveloped. Whereas, $29,4 \%$ (37 people) said it's in the stage of development and it's going to be developed soon. Only 4,8 \%, or just 6 people said that ecotourism in Azerbaijan is developed. There is a correlation between age and opinion about ecotourism of Azerbaijan according to the data analyses. Younger people are more optimistic about ecotourism in the country (Figure 1).

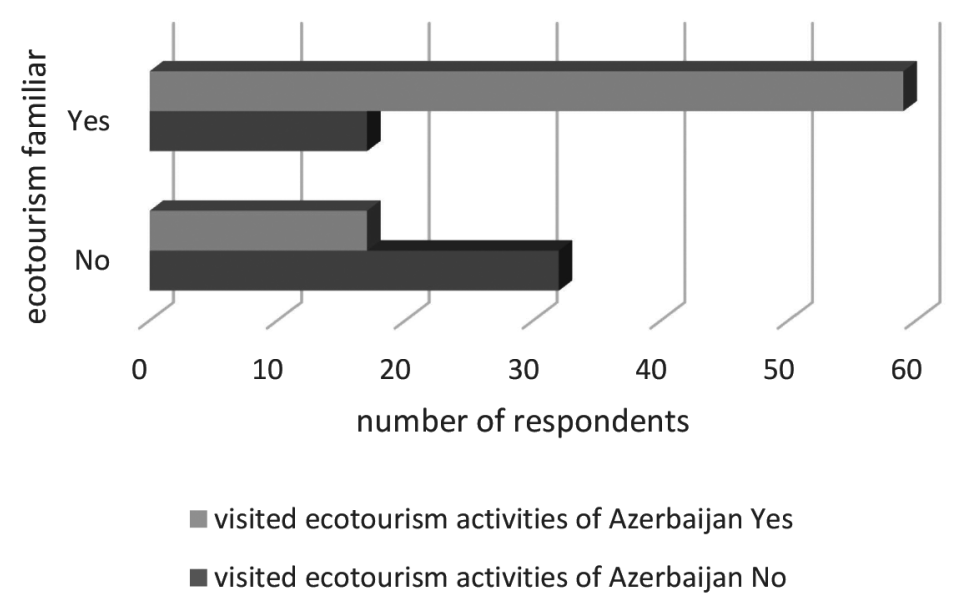

Figure 2. Visited ecotourism activities

Source: based on own data processing and calculations

The vast majority of the participants $(78,4 \%, 98$ people) strongly agreed to research hypothesis of this project which implies that „Azerbaijan has great ecotourism potential, but this potential is not utilized to its fullest capacity". 19 people $(15,2 \%)$ just agreed to this hypothesis, while 8 people $(6,4 \%)$ preferred to stay neutral by neither agreeing nor disagreeing. None of the participants disagreed or strongly disagreed to this hypothesis. Every age group of the survey agreed 
to this statement. 77 people, $61,1 \%$ of the participants took part in some ecotourism activity somehow, while $38,9 \%$ of the participants (49 people) have never participated in any ecotourism activity in Azerbaijan. From here we can see that nature tourism and ecotourism are popular by the majority of the population; however, there are still big numbers of local tourists who don't prefer nature or ecotourism. 2/3 of ecotourist respondents took part in ecotourism activities in Azerbaijan and Azerbaijani National Parks, including SNP. Almost half of the respondents who are not familiar with ecotourism have visited SNP (Figure 2).

The following questions were intended to determine to what degree national parks are being visited by nature loving population and which national parks are popular among them. The results showed that the majority of the participants have never visited national parks in Azerbaijan with the number of $66,7 \%$ or 84 people. $33,3 \%$ (42 people) visited national parks. Goygol NP and Shahdag NP were the most visited national parks. 30,2 \% of participants (38 people) indicated that they visit NPs 1-2 times per year, while just 4,8\% (6 people) said they visit 3-4 times per year; 3,1\% (4 people) answered "5 times and more" per year. The rest majority of 61,9\% of participants (78 people) have not visited NPs in recent years. However, Shahdag region, in general, is a very popular touristic destination. According to survey $56,3 \%$ of participants ( 71 people) have visited SNP or Shahdag region in general, out of which 11 people visited it multiple times. 43,7 $\%$ of participants have never been in Shahdag region in general or SNP in particular. These figures indicate that national parks are not preferred travel options among the nature-loving tourists or general Azerbaijani population. However, almost every participant of the survey (120 people out of 126, or 95,2 \%) said that they know Shahdag NP and they have heard of it. Only 6 people $(4,8 \%)$ have never heard of SNP from out of which 3 are foreign citizens. Although most of the respondents $(0,952)$ have heard about SNP, less than half of them have not visited National Parks at all not depending on the age group. $50 \%$ of the total foreign citizens who participated in the survey have heard of Shahdag National Park from social media, 14,3\% have heard about it from tourism agencies, 7,1 \% from website ads, and 28,6\% have heard about it from other sources.

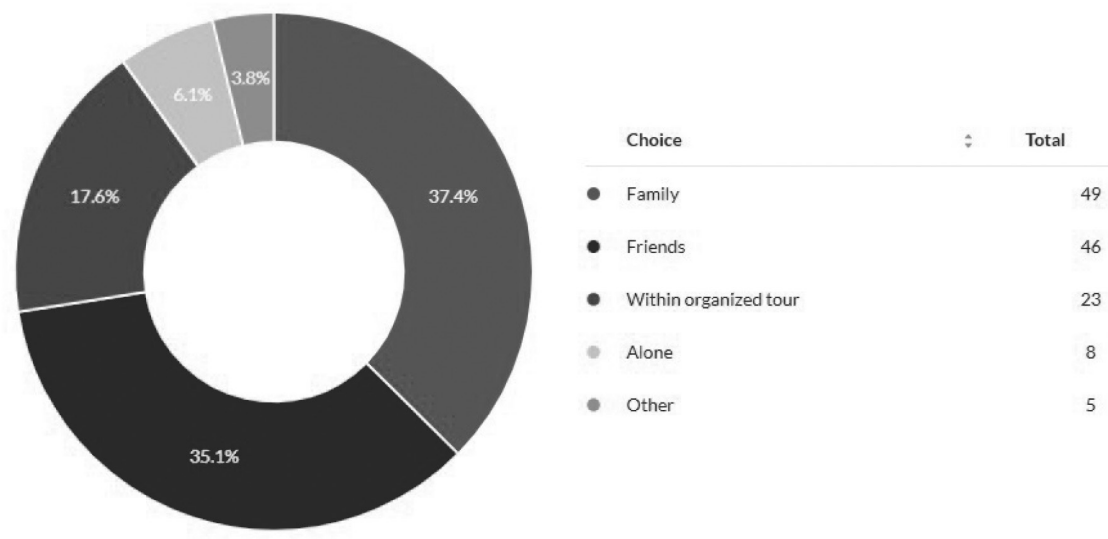

Figure 3. Visiting patterns - With whom did you visit Shahdag National Park?

Source: based on own data processing and calculations

The survey indicated that generally, people of Azerbaijan love to visit national parks or natural destinations with family and friends. $37,4 \%$ of participants (49 people) of those people who visited NPs or would like to visit said they visited with family, and 35,1\% (46 people) with friends. The ones who visited with organized tour were $17,6 \%$ (23 people), $6,1 \%$ (8 people) said they visited alone and $3,8 \%$ (5 people) chose other. This is the clear indication of preference of people being surrounded by family and friends which is, in turn, have been influenced by Azerbaijani culture as well (Figure 3). 
Those ecotourists who visited SNP were 72 participants. Further analyses showed the following pattern. $38 \%$ of those participants visited with family, $36 \%$ with friends, $18 \%$ with organized tour, $7 \%$ visited alone. The transportation method used or preferred to be used in the future by the visitors are mainly personal cars. $53,8 \%$ or 57 travelled by car to SNP. $35,8 \%$ of people used bus. Bicycle was also preferred transportation choice of some visitors with $6,6 \%$. Just one person preferred taxi and 3 people said other transport methods. According to analysis 72 participants (ecotourists) who visited SNP or Shahdag region in general used personal cars as the main method of transportation (49\%), $33 \%$ reached it with a bus, $7 \%$ with bicycle and $11 \%$ with taxi and other methods. Visitors of SNP engaged or want to engage in varied ecotourism activities while their visit to the park. Considering that inside SNP and in surrounding areas of the park there are numerous indigenous settlements and historical places, it was expected that the majority of the visits will have cultural and historical motives. The prediction was correct and the survey indicated that $40,3 \%$ of visitors visited SNP for cultural and historical tours. The second biggest activity with $21 \%$ was skiing and snowboarding which can be explained also by Winter Ski Resort Complex inside the national park area. Hiking was $3^{\text {rd }}$ most famous activity with $17,1 \%$ of participants engaging in that. After that, camping with $11 \%$ and mountain climbing with 8,3\%. Only 4 people said they engaged in other activities (Figure 4). Participation in ecotourism activities doesn't depend on the age group significantly, but it is the least characteristic of the youngest age group according to the data analysis.

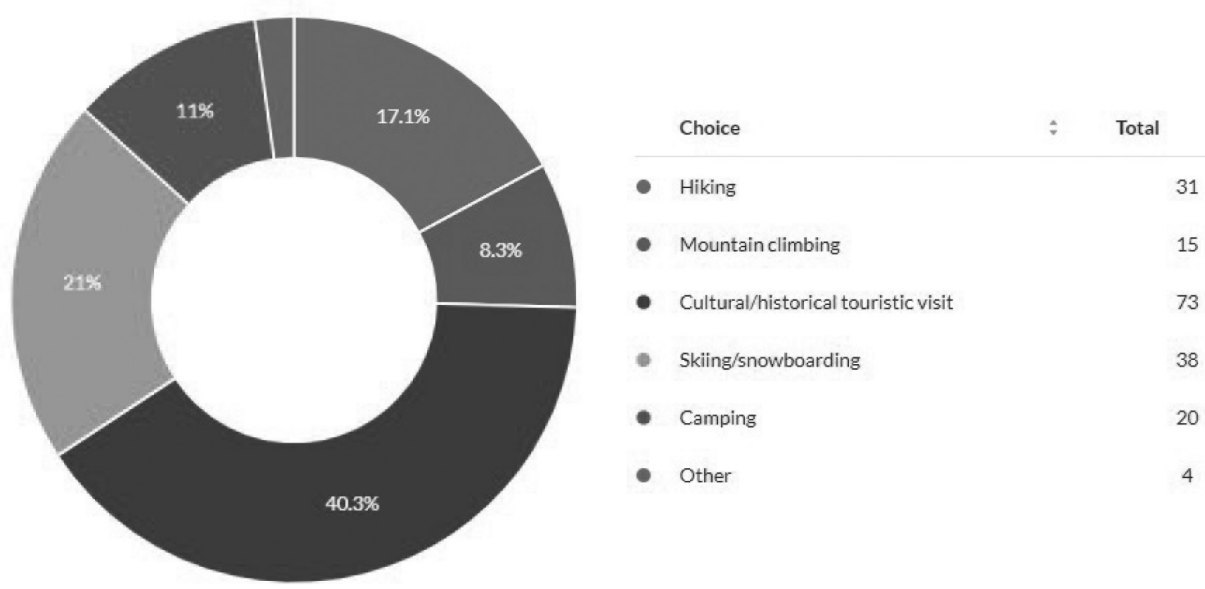

Figure 4. The most popular activities inside the Shahdag National Park area Source: based on own data processing and calculations

The overall 72 people who really visited SNP or Shahdag region in general said they mainly engaged in cultural/historical touristic visit (36\%), $21 \%$ engaged in skiing or snowboarding, $17 \%$ enjoyed hiking, $11 \%$ did camping, $8 \%$ did mountain climbing, $7 \%$ enjoyed hunting and other activities. The overall satisfaction level of visitors of SNP are high. 42,1\% of visitors rated their experience as very satisfied. 34,7 \% said they are just satisfied from their visit. 8,4 \% preferred to stay neutral and chose neither satisfied nor dissatisfied for their experience. 12,6\% of people were dissatisfied. Only 2 people said they are very dissatisfied from their visit to SNP. However, the next question showed another pattern. Although people of Azerbaijan were satisfied with their time spent inside SNP, mainly with their family and friends, but majority of participants did not rate the ecotourism infrastructure of SNP as favourable. Ecotourism infrastructure of the park also included general infrastructure elements such as transportation systems, roads, communication networks, electric systems, safety measures or management facilities. 
The majority of the respondents (47,3\%) rated the ecotourism infrastructure of SNP as bad, viewing it as of low quality, $30 \%$ of respondents said it neither high nor low quality, $13,6 \%$ of respondents said it's very low quality and only $7,3 \%$ of respondents said it is high quality. 2 of the respondents indicated that it is very high quality. It is obvious from these numbers that the ecotourism infrastructure and general infrastructure of Shahdag National Park is in a bad situation and there is a very big need for renovation and reconstruction in this field. The bad infrastructure of the park affects its ecotourism system and overall experience of the visitors negatively. According to data, we can conclude a new pattern, that people do not visit national parks in Azerbaijan mainly because it is underdeveloped. It is shown that the majority of respondents who have never visited SNP or Shahdag region think that ecotourism in Azerbaijan is underdeveloped (Figure 5).

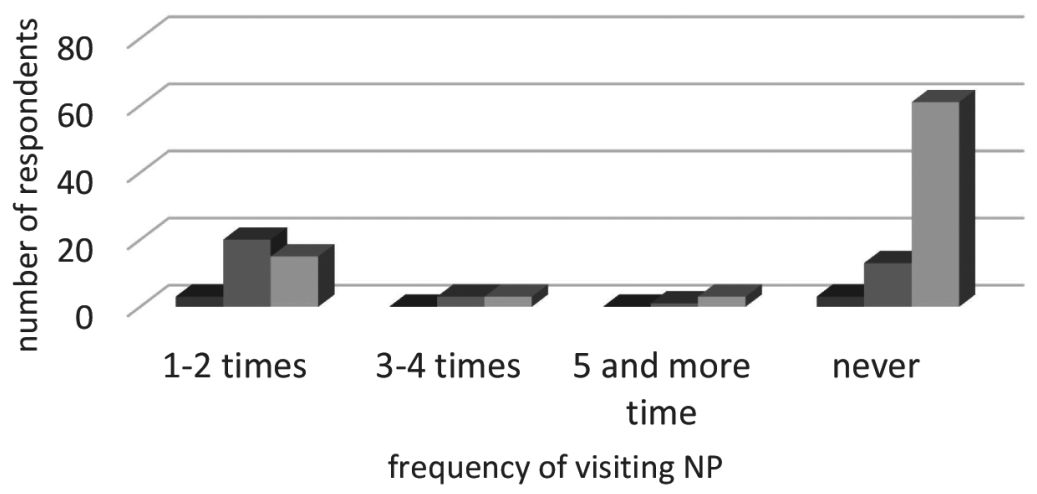

Developed In development stage Unerdeveloped

Figure 5. Visitors of NPs and their opinion

Source: based on own data processing and calculations

Another pattern shows that even the ones who have never visited NPs in Azerbaijan believe that Azerbaijan has great ecotourism potential and those who visited it also believe in this statement. The vast majority of the participants of the survey were very enthusiastic about the future ecotourism perspectives of SNP and 80,16\% of them said they want to see more tourists come to the park in the future. $11,11 \%$ were neutral and $8,73 \%$ of participants did not want the number of visitors to grow in the future. However, together with respondents' optimism in the growing number of tourists, visitors to SNP, the following graph shows their opinion about the consequences of this increase that might happen. The results were also mainly optimistic as $25,3 \%$ of the survey participants said that this increase will attract more investment, thus more and better development to the park. $24,2 \%$ of participants agreed that this inflow of tourists will increase the living standards of indigenous people by allowing them to benefit from this inflow mainly financially. $13,7 \%$ said that nature will be preserved and conserved even better with new, better rules and regulations.

The following graph shows the main disadvantages or challenges of ecotourism inside SNP. Respondents were asked multiple choice questions with a list of detailed possible challenges. The services and activities offered to ecotourists in SNP are limited and there exist a big room and opportunity for improvements, innovations and new possibilities. There are not enough strict and precise rules and regulations in the park policy, safety measures are not appropriate enough. Participants were also asked to choose between offered activities or services. Some of these services already exist at SNP. However, some of them are new for SNP, as well as generally for Azerbaijan such as paragliding, hot air balloon riding, rafting, etc. Surprisingly, participants showed a great interest in such new and extreme activities. These votes show us possible oppor- 
tunities or activities to develop inside the SNP to attract not only local visitors but also foreign visitors. The magnificent natural beauty, high altitude rivers, lakes, highly mountainous landscape and many other natural attributes of SNP not only allows us to develop these activities but also promises a highly successful future of ecotourism system inside its territory. The following chart shows the most common or preferred options chosen by the survey participants (Figure 6).
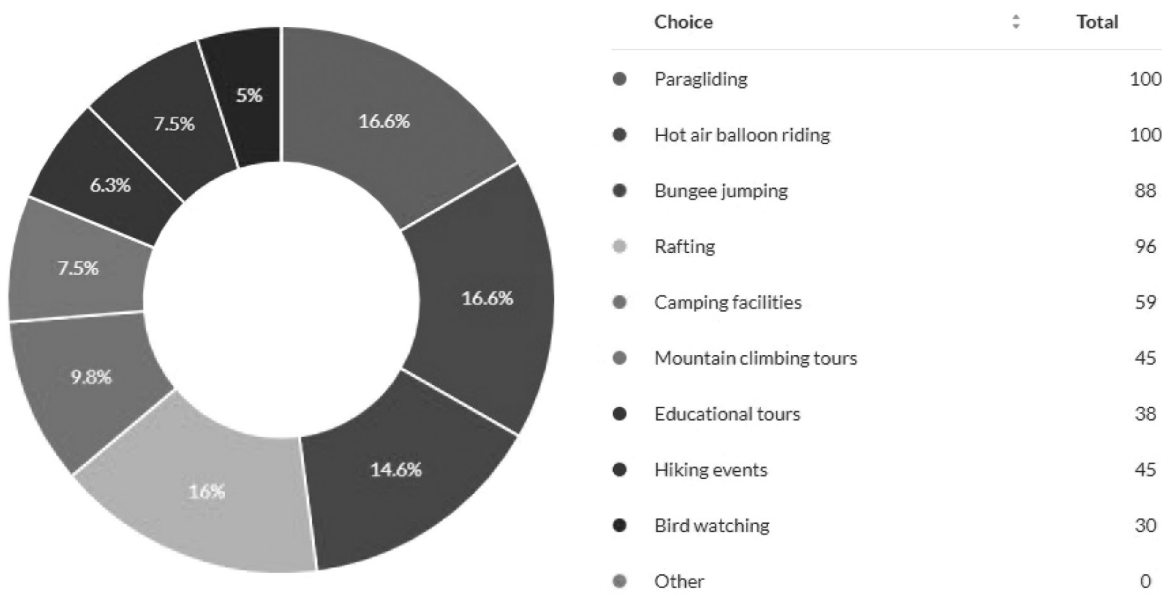

Figure 6. Future development possibilities inside the Shahdag National Park Source: based on own data processing and calculations

\section{CONCLUSION AND RECOMMENDATIONS}

Well-known American researcher and writer in the field of ecotourism Elizabeth Boo developed a framework for developing countries with appropriate ecotourism potential to achieve successful development of sustainable ecotourism system. This framework includes strategies and recommendations for the following steps: Planning, development, and management. However, before the planning, there should be the first preplanning process (Boo, 1990; Whelan, 1991). The preplanning stage comes before the actual planning stage begins. This is the stage where the various government ministries of the country (tourism, finance, agriculture, environment, forestry, parks, planning, public works, and education) have to come together at a round table and discuss the main questions and issues such as: Does ecotourism correspond to the short or long term development goals of the country? This scenario is relevant to the countries with abundant or enough ecotourism products such as beautiful, unusual, and varied natural attractions, appropriate carrying capacities, and demand for ecotourism. It is crucial to include the points and opinions of the private sector, park managers, international funding agencies, local conservation groups, and native communities in the decision-making process.

If the government officials decide to include ecotourism into the development goals of the country, then an Ecotourism Board should be created for further investigation, potential, and development of ecotourism. Members of the board should consist of government representatives, park managers, tour operators, local conservation organizations, the private sector, and native communities. Financial and technological assistance might be gathered from international development and conservation organizations. The main functions of the board are creating a strategy for ecotourism growth. They will oversee the planning, development, and management functions. Sustainable and environmentally sound ecotourism development is a long-term activity. The destinations need to have a documented strategy of promotion and control of tourism in the natural area. In this framework, a key component to success is native communities. 
This research project implemented deep research into the ecotourism system of Azerbaijan, more precisely Shahdag National Park of Azerbaijan. Finally, research questions have been answered, research hypothesis have been accepted, and showcased in the research results and findings section of this paper. Data collection and interviews allowed us to address the main problems of this research. One of the main challenges of ecotourism system of Shahdag National Park is poor ecotourism infrastructure. This includes condition of the roads, electricity system in some parts of the park, water, sewage, heating problems, and some problems related to the communication system, accommodation, lodging and lack of some management facilities. Another challenge is the hard accessibility of the park, also related to poor infrastructure of the SNP. Because of the bad roads or fewer transportation options, it is hard for visitors to reach the park. The next big challenge of SNP and the ecotourism system of Azerbaijan as a whole is the lack of environmental responsibility or ecotourism knowledge among visitors. As mentioned by the director of the Ismayilli region part of Shahdag National Park - Mr. Rafael Musayev, ecotourism is a relatively new phenomenon in Azerbaijan, as well as national parks. There are big problems with littering and abiding by rules within Shahdag National Park. However, the future is promising and people are getting more educated and responsible over time. Lack of ecotourism activities and organized services create another challenge for SNP. If we look to the world practice of successful national park management, we can see varied ecotourism activities and services offered to visitors. These activities include rafting, hot air balloon riding, zip lining, paragliding, bungee jumping, bird watching, varied thematic hiking or camping tours and events, etc. According to the survey, Azerbaijani people are more enthusiastic about these nature extreme and leisure activities, especially hot air balloon riding, rafting, bungee jumping and paragliding. According to the interview, Azerbaijan has lack of experienced workers in the fields of ecotourism and national parks and current specialists are few or some of them are lacking expertise or professional knowledge about these fields. These problems create another challenge for SNP in the management and controlling authority. There might arise some management or controlling problems inside the park management regarding rules, regulations, safety measures and natural preservation and conservation. Although SNP has a good promotion and marketing, this is not at the desired level to boost the popularity of the park and attract more foreign and internal visitors into the park. This is another identified challenge the lack of promotion and marketing of ecotourism inside SNP.

Director, Mr. Rafael Musayev agreed that SNP has great ecotourism potential. He mentioned that they are currently using just $10 \%$ of the ecotourism potential of SNP. The rest of $90 \%$ is still not used and underdeveloped for ecotourism. The vast majority of the survey participants (78,4\%, 98 people) strongly agreed to research hypothesis of this project which implies that „Azerbaijan has great ecotourism potential, but this potential is not used to its fullest capacity". Survey results proved the hypothesis by numbers which showed that they are generally more optimistic about future ecotourism development inside SNP, and they want to increase the numbers of visitors to SNP. The future of ecotourism in the National Parks of Azerbaijan is bright. We can see this from the example of Shahdag National Park and it's future and present perspectives, which were identified by this research and data analyses.

\section{REFERENCES}

A. Barnett, K. A. R. B. A. D. M. F. A. e. a. (2015), Sport fisheries, conservation and sustainable livelihoods: a multidisciplinary guide to developing best practice. s.l.: Fish and Fisheries.

Alizadeh, A. (1986), Lahij - Craftsmen's settlement (ethnographic research of the contemporary way of life). Tbilisi: s.n. 
Azerbaijan Travel (2020), Winter and Summer Adventures at Shahdag. [Online] Available at: https://azerbaijan.travel/enjoy-winter-summer-adventures-shahdag [Accessed 1809 2020].

Azerbaijan Travel (2020), Official Tourism portal of Azerbaijan. [Online] Available at: Azerbaijan.travel [Accessed 2104 2020].

AZERTAG (2020), Tourism in Caucasus. [Online] Available at: https://azertag.az/xeber/1587483 [Accessed 2109 2020].

Boo, E. (1990), Ecotourism: The potentials and Pitfalls. Washington D.C: World Wildlife FundU.S.

Bretanitskiy L.S., M. L. R. U. (1964), Lahij (To the question of urban planning system with its productive specifics). Soviet ethnography, Volume number: 3, p. 129.

Ceballos-Lascurain, H. (1987), The future of ecotourism. Mexico Journal, January. pp. 13-14.

Connor, J. (2001), Hiking in the Caucasus: Sheep dogs, waterfalls, and blanketed hillsides of wildflowers. Azerbaijan International, Vol. 9:2 (Summer), pp. 14-23.

Ә.T.Әsgərov, B. (2011), Ekoloji Turizm (Ecological Tourism). Baku: Adiloğlu nəşriyyat. EMBRATUR, 1999. www.embratur.gov.br. [Online] Available at: www.embratur.gov.br [Accessed 1204 2020].

G.A. Guliyev, N. T. (1968), Metal and folk craft. Baku: s.n.

Gartner, W. (1996), Tourism Development: Principles, Processes and Policies. New York: Van Nostrand Reinhold.

Geography Association of Azerbaijan (2013). Guba region: Khinaliq, Alik and Haput villages. [Online] Available at: https://gsaz.az/articles/view/187/Quba-rayonu-Xinaliq-Alik-vaHaput-kandlari [Accessed 2009 2020].

Holder, J. (1992), The Need for Public-private sector cooperation in Tourism. Tourism Management, 13(2), pp. 157-162.

Honey, M. (1999), Ecotourism and Sustainable Development. Who Owns Paradise?. Washington D.C: Island Press.

IUCN (2020), The International Union for Conservation of Nature, Protected Areas. [Online] Available at: iucn.org [Accessed 2808 2020].

JICA (2017), Japan International Cooperation Agency, Azerbaijan. [Online] Available at: https:// www.jica.go.jp/azerbaijan/english/index.html [Accessed 1809 2020].

Mehmandarova, G., (1998), Khinalig: Linguists' dream, invaders' nightmare. Azerbaijan International, Vol. 6:2 (Summer), pp. 50-51.

Miller, B. (1929), Tats, their settlement and dialects (materials and questions). Baku: s.n.

Ministry of Ecology and Natural Resources (2020), Ecotourism in Shahdag National Park. [Online] Available at: eco.gov.az [Accessed 2208 2020].

Ministry of Ecology and Natural Resources (2020), Rules of behaviour at the territory of National Parks. [Online] Available at: http://eco.gov.az/az/melumat-merkezi/tebii-servetlerimiz/milli-parklar/milli-parklarda-davranis-qaydalari [Accessed 1909 2020].

Müseyibov, M. (1998), Azərbaycanın Fiziki Coğrafiyası (Physical Geography of Azerbaijan). Baku: Maarif Nəşriyyatı.

Nelson, E. R. (2016), Shark Research \& Conservation Program (SRC), University of Miami. [Online] Available at: https://sharkresearch.rsmas.miami.edu/the-three-pillars-of-ecotourism/ [Accessed 2004 2020].

Ski Azerbaijan (2020), Tufandagh Resort, Shahdag Resort. [Online] Available at: kiazerbaijan. com [Accessed 1809 2020].

Steel, P. (1993), The Economics of Ecotourism. s.l.:In Focus 9.

T.O.Ibrahimov (2011), Azərbaycan qoruqlarının ekoloji problemləri (Ecological problems of Azerbaijani National reserves). Baku: Mars print. 
The Ministry of Ecology and Natural Resources of Azerbaijan (2005-2020), Shahdag National Park. [Online], Available at: eco.gov.az, [Accessed 0908 2020] TIES (2015), ecotourism.org. [Online] Available at: ecotourism.org [Accessed 0804 2020]. Wheat, S. (1994), Taming Tourism. s.1.:Geographical 116.

Whelan, T. (1991), Nature Tourism. Managing for the Environment. Washington, D.C: Island Press.

WTO (2001), The British Ecotourism Market, Madrid: World Tourism Organization.

Yusifli, E. (2015), Azerbaijan State Information Agency - AZORTAC. [Online] Available at: https://web.archive.org/web/20200320160617/,

https://azertag.az/xeber/Azerbaycanin_selaleler_diyari__Leze_VIDEO-857856 [Accessed 21 $092020]$. 
